https://doi.org/10.18485/iipe_response2covid19.2021.ch17

\title{
CHINA-CEEC COOPERATION IN THE CONTEXT OF CHINA-EU RELATIONS AMIDST THE POST-PANDEMIC ERA
}

\author{
Hongfei $\mathrm{Gu}^{1}$ \\ Weiwei Ju² \\ Minjia Bian ${ }^{3}$
}

\begin{abstract}
Since its launch in 2012, the China-CEE cooperation mechanism has been a powerful catalyst for practical cooperation between China and the CEE countries in various fields and has become an important driving force for the integration of the Belt and Road Initiative into the European economic sphere. As a model of cross-regional cooperation, China-CEE cooperation has created conditions for the high-quality development of the Belt and Road and has effectively promoted the development of the Belt and Road in areas such as connectivity, transport infrastructure, green energy, financial security, local cooperation, humanities exchanges, and international cooperation in combating pandemics.

At the same time, as part of the China-EU relations, China-CEE cooperation has been questioned by Western public opinion and think tanks, which should be calmly analysed and responded to. In accordance with the principle of "common consultation, common construction and sharing" and bilateralism, regionalism, and multilateralism cooperation, China-CEE relations can be promoted by enriching the level of cooperation, exploring the potential of local cooperation, promoting economic and trade through the humanities, and enhancing capacity.

Therefore, it is important to analyse how China and the CEE countries perceive the relationship and how it can be improved in the context of China-EU relations amidst the post-pandemic era.
\end{abstract}

Keywords: China-CEE relations, COVID-19, Cooperation, China-EU relations.

\footnotetext{
${ }^{1}$ Assistant Professor, School of International Relations, Xi'an International Studies University (XISU), China, Guhf@cass.org.cn.

${ }^{2}$ Assistant Professor, Institute of European Studies, Chinese Academy of Social Sciences (CASS), China.

${ }^{3} \mathrm{PhD}$ Candidate, Department of Diplomacy and Foreign Affairs Management,China Foreign Affairs University (CFAU)
} 
Since the China-CEEC cooperation mechanism was in place, cooperation has been carried out in a wide range of areas at multiple levels and has contributed to China-EU relations. Seen at the China-EU level, as an important part of China-EU relations, China-CEEC cooperation has made positive progress in promoting ChinaEU economic and trade ties, investment cooperation, infrastructural connectivity, and third-party cooperation, and has offered new opportunities for China-EU relations. China-CEE cooperation has contributed significantly to the deepening of cooperation between China and the CEE countries by transforming the loose bilateral cooperation model to the one that combines bilateral and multilateral dimensions, which improved both the quantity and quality of cooperation.

However, in the post-pandemic era, cooperation between the two sides is also facing many new challenges. It is important to take stock of the achievements and experiences of the cooperation between China and the CEE countries and examine the opportunities and challenges that the post-pandemic era brings to China-CEE cooperation in order to promote the cooperation between the two sides in a stable and far-reaching manner.

\section{NARRATIVES OF CHINA-EU COOPERATION IN CHINA-CEE COOPERATION DOCUMENTS}

Guidelines published by the successive China-CEEC Summits (except the one in Warsaw in 2012) have references to the relations between China-CEEC Cooperation and China-EU relations from different angles. China-CEEC cooperation is usually defined as part and parcel of China-EU relations and represents a useful supplement to the China-EU comprehensive strategic partnership.

At the second China-CEEC Summit held in Bucharest, Romania, in 2013, the first guidelines for China-CEEC Cooperation were published. It stressed that ChinaCEEC cooperation was in concordance with the China-EU comprehensive strategic partnership. ${ }^{4}$ Premier Li Keqiang pointed out at the Summit that China-EU cooperation was a fundamental element of the Bucharest Guidelines, and that China-CEEC cooperation was part and parcel of both China-Europe cooperation and China-EU cooperation (FMPRC, 2013). The Belgrade Guidelines for China-CEEC Cooperation, published at the third China-CEEC Summit, pointed out that ChinaCEEC Cooperation was in line with China-EU relations and reaffirmed the commitment to deepening the China-EU partnership for peace, growth, reform,

\footnotetext{
${ }^{4}$ For more information, see: The Bucharest Guideline for Cooperation between China and Central and Eastern European Countries, November 26, 2013, retrieved from http:// www.china-ceec.org/eng/zdogjhz_1/t1410594.htm. Accessed 20 September 2021.
} 
and civilization based on the principles of equality, respect, and trust, thus contributing to the implementation of the China-EU 2020 Strategic Agenda for Cooperation (FMPRC, 2014). At the fourth China-CEEC Summit, the Medium-Term Agenda for China-CEEC Cooperation was published, where it was believed that China-CEEC Cooperation would further advance relations between China and the CEECS and promote the all-round and balanced development of the China-EU comprehensive strategic partnership (FMPRC, 2015). The Riga Guidelines for ChinaCEEC Cooperation, published at the fifth China-CEEC Summit, pointed out that synergy should be developed between China-CEEC Cooperation and the China-EU comprehensive strategic partnership through the China-EU Connectivity Platform and other channels. ${ }^{5}$ The Budapest Guidelines for China-CEEC Cooperation, published at the sixth China-CEEC Summit, reiterated that China-CEEC Cooperation was part and parcel of the overall China-EU cooperation, and the Chinese side reaffirmed the high importance it attached to the China-EU comprehensive strategic partnership, its support for European integration, and its commitment to the ChinaEU partnership for peace, growth, reform, and civilization, and that it was happy to see a Europe enjoying solidarity, stability, and prosperity (FMPRC, 2017). At the seventh Summit, the participants stressed that China-CEEC cooperation was an important part of and a useful supplement to China-EU relations and expressed their readiness to work together, through the China-CEEC format, and in line with their respective competences and existing commitments, to ensure China-EU relations continue to develop in a balanced way. It was also emphasized that the EU member states and candidate countries within the 16 CEECs supported the China-EU partnership for peace, growth, reform, and civilization, as well as the China-EU 2020 Strategic Agenda for Cooperation (FMPRC, 2018). At the eighth Summit, the participants underlined that China-CEEC Cooperation constituted an important part of China-EU relations and complemented China-EU comprehensive strategic partnership and China-EU 2020 Strategic Agenda for Cooperation. They reaffirmed their commitment to deepening their partnership for peace, growth, reform, and civilization. ${ }^{6}$

The narratives of China-EU relations in the successive Guidelines for China-CEEC Cooperation are completely in line with China's EU policy paper. First, it was clearly

\footnotetext{
${ }^{5}$ For more information, see: The Riga Guideline for Cooperation between China and Central and Eastern European Countries, November 27, 2016, retrieved from http://www.chinaceec.org/eng/zdogjhz_1/t1413786.htm. Accessed 20 September 2021.

${ }^{6}$ For more information, see: The Dubrovnik Guideline for Cooperation between China and Central and Eastern European Countries, April 13, 2019, retrieved from http://www.chinaceec.org/eng/zdogjhz_1/t1654339.htm. Accessed 20 September 2021.
} 
stated in China's Policy Paper on the European Union released in 2018 that ChinaCEEC Cooperation is a platform for win-win, open and transparent cross-regional cooperation based on common interests and needs of China and the CEECs and welcomes the support and constructive participation of the EU and other parties (FMPRC, 2018a). This proves once again that China welcomes the involvement of the EU, other European countries and organizations. Second, the content and agenda of China-CEEC Cooperation enrich and complement those of China-EU Cooperation, but are somewhat different in a way that the China-CEEC Guidelines have never stressed the political dimension of the cooperation. Instead, the focus has been on economic cooperation, trade, investment, connectivity, people-topeople exchanges. With practical cooperation as its focus, China-CEEC Cooperation has no intention to undermine China-EU political relations, and the last thing it wants is to bypass the EU and start a regional mechanism on political cooperation with the CEECs. Third, a number of China-CEEC Summits invited representatives of the EU to attend as observers and this shows that the principle of openness and transparency of China-CEEC Cooperation is strictly followed and the EU is always respected as an irreplaceable player in the region.

\section{CHINA-CEEC ECONOMIC COOPERATION IN THE CHINA-EU ECONOMIC RELATIONS}

Through diversified cooperation mechanisms such as economic and trade interaction and investment collaboration, "China-CEEC Cooperation" has become a highlight of the cooperation within China-EU economic relations. Since the establishment of China-CEEC Cooperation, China-CEEC economic cooperation and trade have produced fruitful results, with two-way trade steadily growing and becoming a highlight in China-EU economic relations. We have seen constantly improved bilateral cooperation mechanisms, expanded mutual investment, and smooth infrastructural cooperation. China-CEEC investment cooperation in the infrastructure, energy, and manufacturing sectors has significantly contributed to China-EU economic and trade ties, as evidenced in the following three aspects:

Since the establishment of China-CEEC Cooperation, China-CEEC economic cooperation and trade have produced fruitful results, with two-way trade steadily growing and becoming a highlight in China-EU economic relations. We have seen constantly improved bilateral cooperation mechanisms, expanded mutual investment, and smooth infrastructural cooperation. China-CEEC investment cooperation in the infrastructure, energy, and manufacturing sectors has significantly contributed to China-EU economic and trade ties, as evidenced in the following three aspects: 
First, economic and trade cooperation mechanisms have been improving. The China-CEEC Ministerial Conference on Economic and Trade Promotion, the Business Forum, the Investment Promotion Agencies Contact Mechanism, the Business Council, and the SME Coordination Mechanism were established under the ChinaCEEC Cooperation framework. Meanwhile, the China-CEEC Investment and Trade Expo and the China International Import Expo have become an important avenue for the CEECs to promote their quality products in China, significantly raising the awareness of Chinese customers towards CEEC products. Bilaterally, China and Hungary established working groups on trade promotion with Romania and working groups on e-commerce and investment cooperation with Estonia and Croatia.

Multilaterally, trade mechanisms under the China-CEEC framework play a complementary role in China-EU trade relations. Take the China-CEEC SME Coordination Mechanism, for example. It takes into full account the share of SMEs in CEEC economies and their importance in creating jobs and enhancing competitiveness, and aims to step up SME cooperation and exchanges between China and the CEECs. From 2018 to 2019, two China-CEEC Forums on SME Cooperation were held in Cangzhou, Hebei Province, where multiple cooperation projects were agreed on, with a total value of over 16 billion RMB yuan. Besides, a China-CEEC SME Cooperation Zone was established in 20187, and efforts have been made to put in place a China-CEEC research findings commercialization base, an industrial cooperation base, a CEEC products presentation and trade base, and a cultural exchange centre. Since 2015, the China-CEEC Investment and Trade Expo has been organized in Ningbo. The Expo has since become an important platform related to trade and investment between China and the EU, offering the CEECs a useful opportunity to present their products. In fact, most CEEC businesses are associated with the EU in one way or another, and their trade with China is an important part of China-EU trade. Therefore, the above-mentioned China-CEEC mechanisms have helped advance China-EU business ties.

Second, two-way trade has been steadily growing. According to Chinese Customs statistics, China-EU trade stood at 705.1 billion US dollars, up by $3.4 \%$ year on year, making the EU the largest trading partner of China for 16 consecutive years ${ }^{8}$. As mentioned earlier, the share of China-CEEC trade-in China-EU trade showed a trend of growth in 2019, as China-CEEC trade has been growing year by year, at a rate faster than that of China-EU trade, making it a new driver for ChinaEU trade. The CEECs have a unique advantage and a special role to play in promoting

\footnotetext{
${ }^{7}$ Based in Cangzhou City of Hebei Province of China.

${ }^{8}$ Statistics of Trade between China and European Countries from January to December 2019, March 2, 2020, Ministry of Commerce (PRC).
} 
China-EU trade. By taking advantage of China-CEEC Cooperation, the CEECs are well-positioned to become a hub connecting China with the European high-end market and its advanced industrial capacity. The CEECs are also able to make use of the spillover effect of the fast growth of the Chinese economy to help upgrade their own industries and improve people's livelihood. The constantly improving industrial chain among China, the CEECS, and the EU as a whole has helped develop various sectors in Europe and narrow the economic and social gap between the CEECs and other more advanced parts of Europe.

In addition, the years since the inception of the China-CEEC Cooperation have seen rapid growth in the number of Chinese tourists in the CEECs. According to Chinese statistics, more than six million Chinese tourists visited Europe in 2018, out of which $36.3 \%$ visited Eastern Europe, ranking the first among all parts of Europe, higher than Western Europe (32.8\%), the Nordic states (16.6\%) and Southern Europe (14.2\%). In the first half of 2019, the number of Chinese tourists visiting the CEECs grew by three to five times (China Outbound Tourism Development Annual Report 2019). The immense attraction of the CEECs to Chinese tourists has been translated into an important impetus for economic cooperation and trade between China and the CEECS. Despite a surplus in trade in goods on the part of China towards most CEECs and the EU, there has been a clear surplus on the part of the CEECs and the EU when it comes to tourism.

Third, mutual investment has been expanding. As China-CEEC Cooperation deepens, China's investment in the CEECs has been growing rapidly, with a bigger share in China's total investment in Europe and total foreign direct investment. Although Chinese investment is becoming less concentrated in certain CEECs, distribution among regional countries has been improved. In 2019, Chinese direct investment stock in the 17 CEECs was 2.512 billion US dollars 2019, up by nearly $20 \%$ over 2018, much faster than China's total FDI stock growth. The investment is largely made in machinery manufacturing, chemicals, finance, environmental protection, logistics, and new energy sectors. Mutual investment has brought about cooperation on industrial capacity, a new driving force for China-EU business cooperation. In 2019, EU investment in China stood at 10.42 billion US dollars in real terms, up by $25.7 \%$ over the previous year, while Chinese direct investment in the EU stood at 8.11 billion US dollars, up by $7.1 \% .{ }^{9}$ As China and the CEECs continue to upgrade their relations and the CEECs continue to improve their business environment, China's direct investment has been accumulated to a certain extent,

\footnotetext{
${ }^{9}$ Calculated based on the Statistical Communiqué of China's Foreign Direct Investment in 2019 by the Ministry of Commerce, National Bureau of Statistics and the State Administration of Foreign Exchange of China.
} 
and China-CEEC Cooperation has gradually become a highlight in China's business ties with the EU and the world as a whole.

In the context of difficult times for European integration and Brexit, it is important to strengthen China-CEEC Cooperation, as it will surely help China and the EU in their joint efforts to uphold multilateralism, oppose trade protectionism, increase mutual investment and trade, and step up cooperation in global economic governance.

\section{CHINA-EU CONNECTIVITY ENHANCED THROUGH CHINA-CEEC COOPERATION IN INFRASTRUCTURE CONSTRUCTION}

Infrastructural cooperation between China and the CEECs has not only improved connectivity among the CEECs but also connectivity between the CEECS and other parts of Europe.

China-CEEC Cooperation has made visible progress in infrastructural connectivity. Since 2012, a large number of infrastructural projects in the Balkans have been undertaken by Chinese businesses, such as the Zemun-Borca Bridge and the E763 Highway in Serbia, the Smokovac-Mateševo Highway and a railway renovation project in Montenegro, the Miladinovci-Štip and Kičevo-Ohrid Highways in North Macedonia, and the Peljesac Bridge in Croatia. Chinese businesses also invested in joint projects in the energy and communications sectors in Bosnia and Herzegovina, Romania, Albania, and Estonia to provide the region with better energy and communications support. Good progress is being made in the energy and transport infrastructural projects undertaken by Chinese businesses in Serbia, Bosnia and Herzegovina, Montenegro, and North Macedonia. Many of these projects are part of the pan-European corridors. Apart from China-financed projects, other projects are funded by the EU and built by Chinese businesses, such as the Peljesac Bridge. Through projects invested and constructed by Chinese businesses, China capitalizes on its capital and technological strengths in the infrastructural sector to improve connectivity inside and among the CEECs and between the CEECs and other parts of Europe.

As an important China-CEEC connectivity project, the China-Europe Land-Sea Express Line represents a new trade route connecting the Far East and Europe, on the basis of the Port of Piraeus in Greece and running through North Macedonia, Serbia, Hungary, Austria, the Czech Republic, and Slovakia (Xinhuanet, 2017). While traditional shipping routes run through the Strait of Malacca, the Bay of Bengal, the Indian Ocean and the Cape of Good Hope across the whole south Atlantic and the western African coast before reaching the heart of Europe, this new route, once completed, will open up a brand-new fast track of transportation for trade between 
China and Europe in both directions, reducing transportation time by at least seven to eleven days, compared with traditional shipping routes. The development of this Express Line will create a new situation by improving the logistics of countries along it and speeding up the movement of people, goods, and capital.

As Greece joined China-CEEC Cooperation in April 2019, and its relations with China continue to grow, it will surely make full use of its shipping strengths and ports to be more actively involved, giving the Express Line better prospects. In 2019, 1,000 trains carrying around 80,000 TEUs of goods were operated along the Express Line. It is planned that up to 100 thousand TEUs of goods will be shipped in 2020. This integrated transportation corridor on land and at sea is bringing China and Europe closer to each other.

\section{SIGNIFICANCE AND PROSPECTS OF CHINA-EU THIRD-MARKET COOPERATION IN THE CEECS}

Third-party market cooperation has gradually become a promising field of cooperation between China and European countries. Such cooperation between China and the more advanced economies in Europe also has great potential. The more economically advanced European countries usually have a profound knowledge of the history, culture, and social systems of the CEECs, and their businesses have a strong presence there, who have, over the years, developed rich experience in operating in the region and the EU as a whole. Third-party market cooperation is a good way to facilitate the participation of more developed European countries in the CEEC projects, reduce the risks of Chinese investment in the CEECs, and remove suspicions of certain EU members over the transparency, source of funding, investment returns, and debt risks of China-invested projects. The prosperity of the CEECs will not only help ease the trend of a multi-speed Europe but also narrow the gap between the eastern and western parts of Europe.

So far, China has signed intergovernmental documents on third-party market cooperation with France, Italy, Austria, and the UK, while Germany and Spain have expressed an interest in entering into similar cooperation. For example, the Joint Statement of the fourth round of China-Germany Inter-governmental Consultations (13 June 2016) stated explicitly that China and Germany support third-party market development and cooperation in the infrastructure, finance, and connectivity sectors. The Spanish government was one of the first to establish a working group on third-party market cooperation with the Chinese government, and so far, the two countries have carried out quite a number of joint energy and infrastructural projects in North Africa and the Middle East. 
Third-party market cooperation in the CEECs is still at an early stage. The Devnya Cement Plant project, invested by Italcementi and built by CBMI Construction Co., Ltd. of China, was completed in February 2015. This was the largest contracting project undertaken by a Chinese company in Bulgaria. In November 2019, the Čapljina section of the Corridor 5C Motorway project in Bosnia and Herzegovina, jointly undertaken by China State Construction and PowerChina, started construction. It is financed by the European Investment Bank, with a contractual value of about 100 million euros. It was the first time that Chinese businesses carried out third-party market cooperation in Bosnia and Herzegovina together with the EU. PowerChina plans to implement the Belgrade Subway project in 2020 with a French engineering company involved. Despite the small number of projects jointly implemented by Chinese and Western European companies in the CEECs, China has been able to accumulate some experience in third-party market cooperation after a number of exemplary joint projects with France, Germany, the UK, Italy, Spain, and Austria in Africa and Latin America. This has laid a solid foundation for similar cooperation in the CEECS.

\section{VIEWPOINTS ON CHINA-CEEC COOPERATION AND ITS INFLUENCE ON CHINA-EU RELATIONS}

There have always been doubts and misgivings about China-CEEC Cooperation inside the EU, and the major viewpoints are as follows:

First, "split and rule". Since the establishment of China-CEEC Cooperation, the EU has been suspicious of the intention of the format to split the EU, describing the format as a Trojan horse sent to Europe from China. Such suspicion has always been there. In March 2019, the European Commission released a paper entitled EUChina: A Strategic Outlook, in which China was called a systemic rival of the EU (Hillman \& McCalpin, 2019). This is echoed by some European scholars who think that the EU has realized that China-CEEC Cooperation may further erode the European values and uniformity and result in the division of the EU. In recent years, hit by the migration crisis, populism, and Brexit, the EU has become more sensitive to changes in its external environment, and it has become imperative that the EU maintains internal solidarity and mitigate risks of instability. Chinese efforts to deepen cooperation with the CEECs at this juncture are easily understood by some in the EU as negative.

Second, "rule breaker". The EU attaches great importance to rules and standards and prides itself on being a normative power or rule-based actor. As China grows stronger, the $\mathrm{EU}$ sees China as a rival when it makes the rules, especially after China proposed the Belt and Road initiative. Some EU member states pay close 
attention to the increase of Chinese investment in Europe via the Belt and Road platform and keep stressing the importance of compliance with the rules and standards when the Belt and Road initiative is being implemented. European think tanks criticize some of the Chinese-invested projects in the CEECs for not complying with rules, such as the Budapest-Belgrade Railway (Hungarian section) and highway projects in North Macedonia. Other projects are criticized for adding to the debt risks of the CEECs, such as the Smokovac-Mateševo Highway in Montenegro, and the Stanari Thermal Power Plant in Bosnia and Herzegovina is disputed to be environmentally friendly. These projects are labelled as negative investment projects for alleged non-compliance with EU regulations.

Third, "geopolitical motives". Worried about potential geographical and economic implications brought by China-CEEC Cooperation, the EU is concerned that China may gradually take control of major European infrastructure through its investment projects, which will result in closer relations with the CEECs and more leverage in pressurizing the EU and major EU member states. There are also fears that China may take advantage of the geopolitical and economic influence that it is gradually developing in the CEECs to block some of the EU common policies towards China. Meanwhile, some CEECs may make use of their strong relationship with China to bargain with the EU.

In the face of doubts and misunderstandings of one kind or another, China has been responding through constant dialogue and communication with the EU. It argues that on the one hand, China-CEEC Cooperation is not directed against any other country or organization, and it is merely developing normal state-to-state relations. On the other hand, China will not view its relations with the CEECs in isolation from the larger picture of China-EU relations. On the contrary, it sees ChinaCEEC Cooperation as an important part of China-EU relations.

\section{POST-PANDEMIC COOPERATION BETWEEN CHINA AND CENTRAL AND EASTERN EUROPE}

China-CEEC Cooperation has never been conducted in disregard of the larger picture of China-EU cooperation. It will not only inject positive energy into the European integration process but also help China-EU relations develop in a more balanced manner. The COVID-19 pandemic since the beginning of 2020 has dealt a heavy blow to countries all over the world, including China, both economically and socially. Since the outbreak of this pandemic, the largest public health emergency facing humanity, China and the CEECs have worked hand in hand to weather the challenges. 
While some countries have issued travel bans to and from China, the CEE countries did not show any hesitation to provide aid and have been "working on all fronts" to help the Chinese authorities to fight the disease. The EU's Emergency Response Coordination Centre immediately coordinated all EU Member States to facilitate the delivery of needed personal protective equipment. Firstly, the Commission, under the Cross-border Health Threat Decision, coordinates with the Member States through three key mechanisms (the Early Warning and Response System, the Health Security Committee, and the Health Security Committee's Communicators' network), which "support cooperation, rapid exchange of information, swift monitoring and coordination of preparedness and response measures to COVID-19"; secondly, the Commission, with support from relevant EU agencies, is providing technical guidance related to case definition for diagnosis, infection prevention and control in health care settings, updated information on therapeutics and vaccines, etc.; thirdly, the Commission, with the aim of boosting global preparedness, prevention, and containment of the Coronavirus, offered a fund that is allocated to various sectors; fourthly, the Commission, through the EU Civil Protection Mechanism, has been coordinating the delivery of assistance to China and financing the transport costs of the EU Member States' repatriation flights. At the same time, when China was at its most difficult time, the CEECs lent a helping hand. Hungary and Poland provided China with medical supplies immediately. Polish President Andrzej Duda, Czech President Milos Zeman, and Serbian President Aleksandar Vuele sent letters to President Xi Jinping. First Deputy Prime Minister and Foreign Minister Ivica Daele of Serbia visited China, bringing with him the firm support and friendship of the Serbian people towards the Chinese people. The Czech Philharmonic Orchestra and a Polish blues-rock band voiced support for China through music. The sincerity and assistance of the CEECs were well-received in China.

China understands Europe's circumstances and problems as the virus spreads in EU nations, recalling that the EU and its members expressed their sympathy and support in various forms for China's pandemic prevention and control efforts not long ago. Chinese President Xi Jinping sent a message to President Charles Mitchel of the European Council and President Ursula von der Leyen of the European Commission, conveying sympathies to the EU and the people of its member states over the COVID-19 outbreak. The response to the pandemic should not stop at national borders. China reaffirmed its position to stand firmly with Europe to jointly safeguard regional and global public health security and to protect the lives, safety, and health of people on both sides and beyond. In terms of supporting Europe's outbreak response, China now also actively carries out commercial channels to facilitate Europe's purchase of medical supplies. 
As China gradually put the pandemic under control, the virus quickly spread across Europe. China worked fast to assist the CEECs. On 13 March, a video conference on tackling COVID-19 was organized by the Chinese Ministry of Foreign Affairs, the National Health Commission, the General Administration of Customs, and the Municipal Government of Beijing to share the experience with the CEECs on tackling COVID-19 and step up public health cooperation. The Chinese government, businesses, and NGOs also provided the CEECs with large quantities of supplies necessary for combating COVID-19 by various means. The China-Europe Rail Freight trains and Chinese air carriers shipped a lot of suppliers to the CEECs. A Chinese medical team was sent to Serbia. BGI donated two test laboratories to Serbia and the core facilities of nucleic acid test laboratories to Greece. By donating medical supplies, keeping transportation passages open, dispatching medical experts, and sharing best practices and information, China has taken concrete actions to help the CEECs fight the virus. Meanwhile, projects under the China-CEEC framework are making steady progress. Construction of infrastructural projects undertaken by Chinese businesses in the CEECs, such as the Szczecin Port in Poland and the Peljesac Bridge in Croatia, is underway as planned. The Stanari Thermal Power Plant in Bosnia and Herzegovina and the Smederevo Steel Plant in Serbia, invested and operated by China, are running well. An online Information Exchange and Matchmaking Conference between Chinese and the CEEC SMEs on Resuming Work and Production was held in June in Beijing, and over 300 businesses took part and signed nearly 70 cooperation agreements. These have offered the CEECs support and help as they work hard to stabilize their economies. Cooperation during the pandemic has added a new dimension to China-CEEC Cooperation and opened up new possibilities and prospects for their cooperation in the future.

\section{CONCLUSION}

China-CEEC Cooperation is a cooperation platform jointly built by China and the CEECs that aims to promote growth in both China and the CEECs and contribute to European integration. China has no geopolitical intentions behind its cooperation with the CEECs, and firmly supports European integration. The EU is an important force for world peace and stability and the largest trading partner of China. A united, stable and prosperous EU is in the fundamental interest of China. Just like proposals such as a multi-speed Europe or reshaping Europe, China-CEEC Cooperation is also committed to more balanced and thorough development of the European economy and, ultimately, European integration. China-CEEC Cooperation has always abided by internationally recognized rules, including the WTO rules, respected EU legislation and regulations, stayed committed to consultation and sharing benefits, and urged businesses to follow the market and business rules when they bid for 
European projects without making any exclusive arrangements. It has proven to be an open, transparent, and inclusive cooperation platform that injects impetus into China-CEEC relations and contributes additionally to China-EU's comprehensive strategic partnership.

In a globalized era, shared opportunities and risks are inevitable. People and goods are constantly moving all over the world, so do pathogen agents. Public health emergencies are a common problem facing mankind. Viruses have no barriers. Humanity has become a community of prosperity but also of destruction. In this globalized era, there is no country able to develop without associating with others. At this moment, the top priority is to cooperate, share experience, as well as work together. Developing a sense of community with a shared future for humanity, thereby winning the battle against the novel coronavirus pneumonia pandemic is our common goal. After the outbreak of this pandemic, China has made enormous efforts to protect its people and assume responsibility as a major power to contain the spread of the virus worldwide. China's combat against COVID-19 has set an example of building a global community with a shared future for all mankind. The most radical and strictest measures taken by China are not only to safeguard and ensure the health of Chinese people, but also to secure the health of people around the world.

We are now facing a new world where there are new insecurities and health is a rising issue on the agenda of China-CEE relations. Today, both China and the CEE countries are key players in global health governance, and a health partnership has emerged between them. The COVID-19 crisis is a significant test for their health partnership. By now, the two partners have maintained close contact, and health aid has been delivered mutually. The pandemic underlines the global interdependence and the critical role of China and the CEE countries in dealing with such challenges. In the short term, the two partners should keep in close contact about the disease's progression and offer assistance to one another. In the long run, China and the CEE countries may consider further lifting the role of health on their political agenda, and the CEE countries may engage with China's health system reform more actively. The "Belt and Road" Initiative could serve as a platform for strengthening their health cooperation, so as to jointly build a community with a shared future for mankind.

\section{REFERENCES}

Baiyi, W., Yuzhen, H., and Zuokui, L. (2020). China-CEEC Cooperation Progress and Evaluation Report (2012-2020), China Social Sciences Press. 
Brînză, A. (2021). How China's 17+1 Became a Zombie Mechanism, The Diplomat, retrieved from https://thediplomat.com/2021/02/how-chinas-171-became-azombie-mechanism/. Accessed 20 September 2021.

China Outbound Tourism Development Annual Report. (2019). China Tourism Academy.

China's Policy Paper on the European Union, December 18, 2018, retrieved from https://www.fmprc.gov.cn/mfa_eng/wjdt_665385/2649_665393/t1622890.sht ml. Accessed 20 September 2021.

Empty shell no more: China's growing footprint in Central and Eastern Europe, AMO, 2020.

Five-year Outcome List of Cooperation Between China and Central and Eastern European Countries, November 28, 2017, retrieved from https://www.fmprc. gov.cn/mfa_eng/zxxx_662805/t1514538.shtml. Accessed 20 September 2021.

FMPRC. (2013, 27 November). Premier Li Keqiang Attends China-CEEC Summit, retrieved from https://www.fmprc.gov.cn/mfa_eng/topics_665678/lkqcxzdogj Idrhwbdlmnyjxzsgsfwcxshhzzzcygzlhy/t1103607.shtml. Accessed 20 September 2021.

FMPRC. (2014, 17 December). The Belgrade Guidelines for Cooperation between China and Central and Eastern European Countries, December 17, 2014, retrieved from https://www.fmprc.gov.cn/mfa_eng/zxxx_662805/t1224905. shtml. Accessed 20 September 2021.

FMPRC. (2015, 25 November). The Medium-term Agenda for Cooperation between China and Central and Eastern European Countries, retrieved from https://www.fmprc.gov.cn/mfa_eng/zxxx_662805/t1318038.shtml. Accessed 20 September 2021.

FMPRC. (2017, 28 November). The Budapest Guideline for Cooperation between China and Central and Eastern European Countries, retrieved from https://www.fmprc.gov.cn/mfa_eng/zxxx_662805/t1514534.shtml. Accessed 20 September 2021.

FMPRC. (2018, 9 July). The Sofia Guideline for Cooperation between China and Central and Eastern European Countries, retrieved from https://www.fmprc. gov.cn/mfa_eng/wjdt_665385/2649_665393/t1577455.shtml. Accessed 20 September 2021.

FMPRC. (2018a, 18 December). China's Policy Paper on the European Union, retrieved from https://www.fmprc.gov.cn/mfa_eng/wjdt_665385/2649_ 665393/t1622890.shtml. Accessed 20 September 2021. 
Góralczyk, B. (2017). China's Interests in Central and Eastern Europe: Enter the Dragon, European View, 16(1), pp. 153-162.

Hillman, J. E., McCalpin, M. (2019). Will China's '16+1' Format Divide Europe? CSIS Report.

Jinping, X. (2021). Keeping up the Momentum and Working Together for A New Chapter in China-CEEC Cooperation, Keynote Speech by Chinese President Xi Jinping at the China-CEEC Summit.

Joint Statement of the Fourth Round of China-Germany Inter-governmental Consultations, June 13, 2016.

Maric, N. and Ling, W. (2018) "Pragmatic Institutionalism: China - Central and Eastern European Cooperation", Journal of World Economics and Politics, (7), pp. 41-67.

Stanzel, A., Kratz, A., Szczudlik J. \& Pavlićević, D. (2016). China's Investment in Influence: The Future of 16+1 Cooperation, European Council on Foreign Relations.

Szunomár, A. (2018). One Belt, One Road: Connecting China with Central and Eastern Europe?, in: Cheng, Y., Song, L., Huang, L. (eds.) The Belt \& Road Initiative in the Global Arena, Singapore, Palgrave MacMillan.

The Bucharest Guideline for Cooperation between China and Central and Eastern European Countries, November 26, 2013, retrieved from http://www.chinaceec.org/eng/zdogjhz_1/t1410594.htm. Accessed 20 September 2021.

The Dubrovnik Guideline for Cooperation between China and Central and Eastern European Countries, April 13, 2019, retrieved from http://www.chinaceec.org/eng/zdogjhz_1/t1654339.htm. Accessed 20 September 2021.

The Riga Guideline for Cooperation between China and Central and Eastern European Countries, November 27, 2016, retrieved from http://www.chinaceec.org/eng/zdogjhz_1/t1413786.htm. Accessed 20 September 2021.

Xinhuanet. (2017, 9 May). Connected by the Land-Sea Express Line, China and the EU Jointly Build Maritime Silk Road, retrieved from http://www.xinhuanet.corn/ $\mathrm{mrdx} / 2017-05 / 09 /$ c_136267884.htm.

Zuokui, L. (2020). The Development Process and Prospects of Cooperation between China and Central and Eastern European Countries, Contemporary World (in Chinese). 